\title{
REVIEW
}

\section{Particularities of arrhythmias and obesity in heart failure}

\author{
Alexandra Dadarlat-Pop', Dana Pop², Anca Buzoianu
}

\begin{abstract}
Chronic heart failure and obesity are two conditions which despite all the advances made in the recent years, still represent two of the leading causes of morbidity and mortality worldwide. Moreover, a well-known fact is that the risk of sudden cardiac death, mostly related to malignant arrhythmias is higher in apparently healthy obese individuals in comparison with lean subjects. On the other hand, obese heart failure patients bring unique challenges in the diagnosis of heart failure, having a better prognosis than their normal or underweight counterparts. Taking into account the above-mentioned existing data, there are questions regarding whether cardiac arrhythmias such as atrial fibrillation or ventricular arrhythmias in this population have certain evolutive particularities. This paper describes various mechanisms of cardiac arrhythmias found in obese heart failure patients, such as myocardial architectural changes, neurohormonal and paracrine modifications. Keywords: heart failure, rhythm disorders, obesity.
\end{abstract}

Rezumat: Insuficiența cardiacă cronică și obezitatea sunt două afecțiuni care, în ciuda tuturor progreselor înregistrate în ultimii ani, reprezintă încă două dintre principalele cauze ale morbidității și mortalității la nivel mondial. Mai mult chiar, riscul de moarte subită cardiacă, în cea mai mare parte legat de aritmii maligne, este mai mare la persoanele obeze aparent sănătoase, în comparație cu subiecții normoponderali. Pe de altă parte, pacienții obezi cu insuficiență cardiac, dificil de diagnosticat din punct de vedere al afecțiunii cardiace, au un prognostic mai bun decât omologii lor normoponderali și mai ales subponderali. Ținând cont de datele existente menționate, ne-am pus problema dacă aritmiile cardiace, cum ar fi fibrilația atrială sau aritmii ventriculare, prezente la această categorie de pacienți au anumite particularități evolutive. Acest referat descrie diferitele mecanisme implicate în apariția aritmiilor cardiace la pacienții cu insuficiență cardiacă și obezitate, cum ar fi modificările ,arhitecturale” miocardice, dar și cele neurohormonale și paracrine.

Cuvinte-cheie: insuficiență cardiacă, aritmii cardiace, obezitate.

\section{OBESITY AND HEART FAILURE}

Both, heart failure and obesity represent major public health problems with extremely high mortality rates, the mortality due to heart failure being evaluated by up to $50 \%$ at 5 years of evolution, despite the data provided by important studies such as Framingham Heart and Olmsted County Studies, which showed significant improvements in the survival of the patients with heart failure in the last years $\mathbf{1}^{1,2}$.

Obesity is an independently acknowledged cardiovascular risk factor, being significantly implicated in the development of heart failure. In Europe, obesity affects $21.5 \%$ and $24.5 \%$ of men, respectively women ${ }^{3}$.

\footnotetext{
' Department of Cardiology, ,Niculae Stăncioiu” Heart Institute, ClujNapoca, Romania

${ }^{2}$ Department of Cardiology, Clinical Rehabilitation Hospital, ClujNapoca, Romania

${ }^{3}$ Department of Pharmacology, Toxicology and Clinical Pharmacology, „,uliu Hatieganu” University of Medicine and Pharmacy, Cluj-Napoca, Romania
}

Age-related relative risk of developing cardiovascular pathology is approximately $20 \%$ and $40-60 \%$ higher for overweight, respectively obese patients than in the general population ${ }^{4}$. Approximately $11 \%$ of cases of heart failure in men and $14 \%$ in women have obesity as a unique aetiology 4 .

The Framingham study showed an increase in the risk of developing heart failure by $5 \%$ for males and $7 \%$ for women for every one-point increase in BMI over 25. In comparison with normal weight subjects, the risk of heart failure is two-fold higher in obese patients, with a relative risk of 2.12 for females and 1.90 for males 5 . Most patients with obesity develop heart

\footnotetext{
$\checkmark$ Contact address:

Dana Pop, Department of Cardiology, Clinical Rehabilitation Hospital, 46-50 Viilor Street, Cluj-Napoca 400347, Romania.

E-mail: pop67dana@gmail.com
} 
failure with preserved left ventricular ejection fraction due to a significant decrease in ventricular distensibility in response with their hypervolemic state ${ }^{6}$. The cardiac fibrosis leads to impaired ventricular diastolic filling and also, to important microcirculatory derangements ${ }^{6}$.

Obesity leads to systemic inflammatory state, with serious effects on the cardiovascular system. It may influence the coronary arteries, by accelerating the atherosclerosis process, even though the exact mechanism remains not entirely described. Also, the accumulation of epicardial adipose tissue has important implications in the development of cardiac mechanical or electrical disturbances. Moreover, it seems to be in close association with presence and severity of coronary ischaemic disease ${ }^{6}$. The hyperaldosteronism described in obese individuals enhance the fibrotic process, heart failure obese patients responding very well to mineralocorticoid receptor antagonists treatment.

\section{THE OBESITY PARADOX}

Heart failure diagnosis poses more challenges in obese patients because the classic signs and symptoms, such as dyspnea, decreased exercise tolerance are more difficult to identify, the echocardiographic window is often inadequate, and the diagnostic and prognostic markers are in lower concentrations I. However, patients with overweight or obesity and heart failure have a better prognosis than normal weight patients or those with cardiac cachexia, phenomenon which is known as the ,paradox of obesity”.
A meta-analysis of six studies which included 22.807 patients with heart failure demonstrated that the higher the BMI, the more important cardiovascular events are registered (cardiovascular mortality, mortality of any cause, number of rehospitalization for 2.9 years) ${ }^{7}$. Moreover, a reverse relationship between the level of NT-pro-BNP and BMI has been described ${ }^{8}$.

Although there is strong evidence supporting this paradox, the relationship between obesity and heart failure's prognosis is still uncertain. Greater metabolic reserves, secretion of protective cytokines, younger age or earlier presentation, different aetiologies of heart failure, increased muscle mass and muscular strength, attenuated response to renin-angiotensinaldosterone system or non-purposeful weight loss are all responsible for a better prognosis' ${ }^{9}$. On the other hand, this paradox was not found in patients with diabetes mellitus and heart failure without obesity ${ }^{10,11}$.

However, the "obesity paradox" seems to disappear with an important increase of the BMI'2.

\section{POSSIBLE ARRHYTHMIAS' MECHANISMS IN OBESE HEART FAILURE PATIENTS}

There is a strong relationship between obesity, epicardial fat and cardiac arrhythmias. The Framingham study has shown that obese individuals apparently healthy have a 40 -fold higher risk of sudden cardiac death than lean subjects ${ }^{13}$. Moreover, one of the leading causes of death in heart failure patients are cardiac arrhythmias, which are frequently found in patients

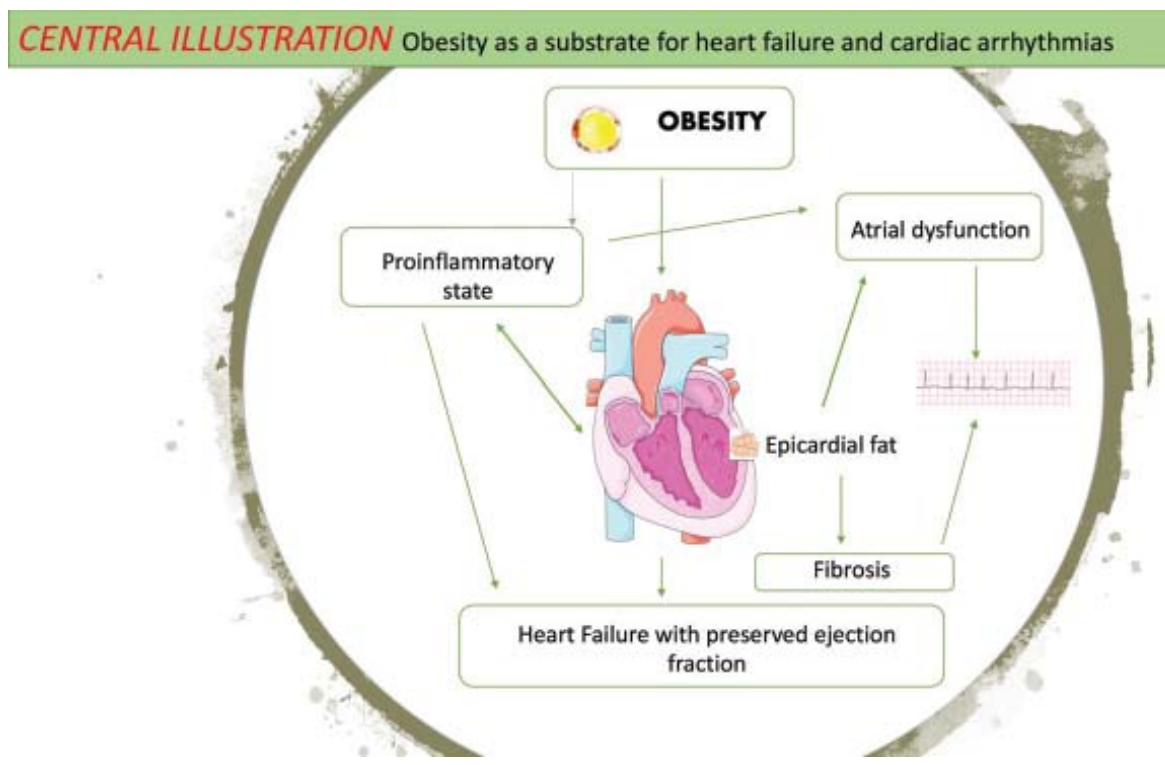

Figure I. Links between obesity, heart failure and cardiac arrhythmias. 
with heart failure and obesity in the clinical practice. We summarize below some of the possible mechanisms involved in the development and progression of these arrhythmias.

Conduction disorders. The infiltrative and metaplastic changes described in this category of patients may affect the cardiac conduction system, such as the sinus node, the atrioventricular node, the right bundle branch of the His fascicle, but also the myocardium surrounding the atrioventricular ring, which may lead to various conduction disorders: sinoatrial block, right bundle branch block, rarely even atrioventricular block ${ }^{14}$. These changes occur when the adipose cells most often from the epicardial level accumulate between the muscle fibers or lead to their degeneration $^{14}$. In the recent years, the role of epicardial and pericardial fat, two embryologically distinct forms of adipose tissue, was intensively studied in relation to the development of several cardiac arrhythmias ${ }^{15}$. The epicardial fat is responsible for secreting different metabolic factors, such as free fatty acids, angiogenic factors, growth and remodeling factors, adipocytokines (adiponectin, leptin), inflammatory cytokines and chemokines and various interleukins, plasminogen activator inhibitor-I, tumour necrosis factor alpha. On the other hand, the pericardial fat serves more as a depot of adipose tissue, sharing similar endocrine, paracrine and autocrine functions with the visceral adipose tissue.

Myocardial architectural changes especially left ventricular hypertrophy described in this population involve coronary flow changes leading to a myocardial arrhythmogenic substrate ${ }^{4}$. Moreover, sympathetic hyperreactivity and elevated serum catecholamine levels have an important additional contribution to the development of cardiac arrhythmias. Moreover, high free fatty acids concentrations may also affect repolarization. Apparently a 10\% increase in body weight decreases the parasympathetic tone and increases the heart rate ${ }^{4}$. There is recent data showing that remodeling of calcium homeostasis has an important role in cardiac arrhythmias development in patients with diabetes mellitus and obesity ${ }^{16}$.

Atrial fibrillation. By far, the most common supraventricular arrhythmia is atrial fibrillation. Atrial fibrillation is frequently seen in patients with heart failure, irrespective of their left ventricular ejection fraction, complicating their prognosis through the associated thromboembolic risk and by worsening the systolic dysfunction and also exacerbating the symptomatology'. The occurrence of atrial fibrillation in patients with heart failure is a marker of poor prognosis. The data from a recent registry-EuroObservational Research Program HF Long-Term Registry shows that atrial fibrillation is present in $44 \%$ of patients hospitalized for acute heart failure and in $36.7 \%$ of patients with chronic heart failure ${ }^{17}$.

There are studies suggesting that obesity is an independent risk factor for the development of atrial fibrillation, the risk being directly proportional to the BMI value ${ }^{18,19}$. Atrial dilatation and atrial dysfunction secondary to the obesity-induced cardiomyopathy are largely responsible for the onset, recurrence or progression of atrial fibrillation. The atrial remodeling is often accompanied by electrophysiological changes, such as shortening of the atrial refractory period, as well as by surface electrocardiogram modifications regarding the $P$ wave length, $P R$ interval or the negative terminal force of the $P$ wave ${ }^{20}$.

Other mechanisms incriminated in triggering this arrhythmia in obese heart failure patients are the adipose tissue accumulation in the left atrium posterior wall, which independently associates with the development of atrial fibrillation, intramyocardial fibrosis favoring the re-entry circuits, as well as the paracrine mechanisms, various adipo-fibrokines having pro- arrhythmogenic effects ${ }^{15,20}$. The release from the epicardial fat of several inflammation biomarkers, such as tumour necrosis factor- $\alpha$ and interlukin-I may lead to atrial fibrillation development ${ }^{15}$. In the Framingham Heart Study, epicardial volume fat was associated with an increase in the prevalence of atrial fibrillation after adjustment for atrial fibrillation risk factors, BMI and other ectopic fat depots ${ }^{21}$. Recent studies show that obese patients suffering from heart failure with preserved ejection fraction and atrial fibrillation have a substantial lower risk of death of any cause or of rehospitalization for decompensated heart failure compared to normal weight patients ${ }^{22}$. Atrial fibrillation is an independent marker of all-cause mortality and rehospitalization for decompensated heart failure in patients with heart failure with preserved ejection fraction and a BMI $<25 \mathrm{~kg} / \mathrm{m}^{2} 23$.

Of note that there is evidence regarding the presence of the "obesity paradox" phenomenon also in overweight/ obesity patients with atrial fibrillation being efficiently anticoagulated, in terms of complications such as all cause-mortality, stroke incidence, systemic 
embolism, myocardial infarction to lean AF patients, class I obese patients with AF having a $35 \%$ lower risk of all-cause mortality than those with normal BMI24,25. The mechanisms underlying this phenomenon are not well understood and many confounding factors may be implicated. First, lean individuals are significantly older in most of the observational cohorts, knowing that age is a powerful predictor of mortality in AF patients. On the other hand, studies suggest a more aggressive management of $A F$ in obese patients as compared with their leaner counterparts. Also, a normal BMI may be due to several pathological catabolic conditions ${ }^{26}$. In the Aristotle study, the presence of obesity was shown to be associated with a better survival in patients with atrial fibrillation efficiently anticoagulated, regardless of the inflammation biomarkers values or the presence of renal impairment ${ }^{27}$.

However, a meta-analysis of $5 \mathrm{I}$ studies involving 626603 patients showed that the presence of obesity in post-operative and post-ablation patients is associated with an increased risk of recurrence of this arrhythmia, by 19 to $29 \%$ for each $5 U$ increment of $\mathrm{BMI}^{28}$. The presence of epicardial fat has also been associated with an increased risk of post-ablation atrial fibrillation recurrence ${ }^{29}$.

Ventricular arrhythmias. Usually, patients with heart failure with preserved ejection fraction exhibit supraventricular arrhythmias, while those with heart failure with reduced ejection fraction develop ventricular arrhythmias ${ }^{26}$.

Ventricular arrhythmias occur 40-60 times more frequently in morbidly obese than in general population of similar age. Ventricular arrhythmias are common in heart failure patients, approximately $87 \%$ of them have isolated or coupled premature ventricular contractions and $45 \%$ present non-sustained ventricular tachycardia ${ }^{30}$. Ventricular extrasystoles are also 30 times more common in obese patients with left ventricle hypertrophy, and the complexity of ventricular ectopicities correlates with left ventricular diastolic diameter and left ventricular mass ${ }^{31}$. A particular feature of this group of patients is the prolongation of the QTc interval. Electrophysiological studies in subjects with obesity have shown increased electrical irritability, which can trigger ventricular arrhythmias, even in the absence of ventricular dysfunction or heart failure. One of the possible mechanisms is the increase in insulin resistance commonly described in obese heart failure patients ${ }^{12}$. The prognosis of obese heart failure patients, who have an indication for implantable cardioverter-defibrillator (ICD) placement in primary prevention is similar to that of normal weight patients ${ }^{32}$. However, studies show that cardiac-resynchronization therapy with an implantable defibrillator in obese patients with advanced chronic non-ischemic heart failure does not bring significant additional benefits to ICD, as clearly seen in those with an ischemic aetiology ${ }^{33}$.

To conclude with, even though the prognosis of obese patients with heart failure is better than in normal weight or cachectic population, arrhythmias occur quite frequently and complicate their evolution, having certain particular features that need to be emphasized and properly treated.

\section{Conflict of interest: none declared.}

\section{References}

I. Ponikowski P, Voors AA, Anker SD, Bueno H, Cleland JG, Coats AJ, et al. 2016 ESC Guidelines for the diagnosis and treatment of acute and chronic heart failure: The Task Force for the diagnosis and treatment of acute and chronic heart failure of the European Society of Cardiology (ESC) Developed with the special contribution of the Heart Failure Association (HFA) of the ESC. Eur Heart J 2016;37 (27):2129-200.

2. Bastien M, Poirier P, Lemieux I, Després JP. Overview of epidemiology and contribution of obesity to cardiovascular disease. Prog Cardiovasc Dis. 2014;56:369-8I.

3. Yumuk VI, Tsigos C, Fried M, Schindler K, Busetto L, Micic D, Toplak H. Obesity Management Task Force of the European Association for the Study of Obesity. European Guidelines for Obesity Management in Adults. Obes Facts. 2015;8(6):402-24.

4. World Health Organization: Obesity and Overweight. WHO fact sheet No 31I, Geneva, WHO, 2015. www.who.int/mediacentre/ factsheets/fs3I I/en/ (last accessed November 30, 20I5).

5. Mathew B, Francis L, Kayalar A, Cone J. Obesity: effects on cardiovascular disease and its diagnosis. J Am Board Fam Med. 2008;2I(6): 562-8.

6. Packer M. Epicardial Adipose Tissue May Mediate Deleterious Effects of Obesity and Inflammation on the Myocardium. J Am Coll Cardiol. 20I8;7I(20):2360-72.

7. Guglin M, Baxi K, Schabath M. Anatomy of the obesity paradox in heart failure. Heart Fail Rev. 2014;19(5):621-35.

8. Horwich TB, Fonarow GC, Clark AL. Obesity and the Obesity Paradox in Heart Failure. Prog Cardiovasc Dis. 20I8;6I(2):I5I-I56.

9. López-J, Cortés-Bergoderi M. Update: systemic diseases and the cardiovascular system (i): obesity and the heart. Rev Esp Cardiol. 201 I;64(2): 140-9.

10. Sharma A, Lavie CJ, Borer JS, Vallakati A, Goel S, Lopez-Jimenez F, Arbab-Zadeh A, Mukherjee D, Lazar JM. Meta-analysis of the relation of body mass index to all-cause and cardiovascular mortality and hospitalization in patients with chronic heart failure. Am J Cardiol. 2015; I 15:1428-34.

II. Ndumele CE, Matsushita K, Sang Y, Lazo M, Agarwal SK, Nambi V, Deswal A, Blumenthal RS, Ballantyne CM, Coresh J, Selvin E. N-Terminal Pro-Brain Natriuretic Peptide and Heart Failure Risk Among Individuals With and Without Obesity: The Atherosclerosis Risk in Communities (ARIC) Study.Circulation. 2016; I33(7):631-8.

12. Lavie CJ, De Schutter A, Parto P, Jahangir E, Kokkinos P, Ortega FB, Arena R, Milani RV. Obesity and Prevalence of Cardiovascular Diseases and Prognosis-The Obesity Paradox Updated. Prog Cardiovasc Dis. 2016;58(5):537-47. 
13. Kannel WB, Plehn JF, Cupples LA. Cardiac failure and sudden death in the Framingham Study. Am Heart J 1988; I 15:869 -75.

14. Adamopoulos C, Meyer P, Desai RV, Karatzidou K, Ovalle F, White M, Aban I, Love TE, Deedwania P, Anker SD, Ahmed A. Absence of obesity paradox in patients with chronic heart failure and diabetes mellitus: a propensity-matched study. Eur J Heart Fail. 20I I; I3(2):2.

15. Wong CX, Sun MT, Odutayo A, Emdin CA, Mahajan R, Lau DH, Pathak RK, Wong DT, Selvanayagam JB, Sanders P, Clarke R. Associations of Epicardial, Abdominal, and Overall Adiposity With Atrial Fibrillation. Circ Arrhythm Electrophysiol. 2016;9(12). pii: e004378

16. Hamilton S, Terentyev D. Proarrhythmic Remodeling of Calcium Homeostasis in Cardiac Disease; Implications for Diabetes and Obesity. Front Physiol. 2018;9:1517.

17. Maggioni AP, Dahlstrom U, Filippatos G, Chioncel O, Crespo Leiro M, Drozdz J, Fruhwald F, Gullestad L, Logeart D, Fabbri G, Urso R, Metra M, Parissis J, Persson H, Ponikowski P, Rauchhaus M, Voors AA, Nielsen OW, Zannad F, Tavazzi L; Heart Failure Association of the European Society of Cardiology (HFA). EURObservational Research Programme: regional differences and I-year follow-up results of the Heart Failure Pilot Survey (ESC-HF Pilot). Eur J Heart Fail 2013;15:808-17.

18. Wang HJ, Si QJ, Shan ZL, Guo YT, Lin K, Zhao XN, Wang YT. Effects of body mass index on risks for ischemic stroke, thromboembolism, and mortality in Chinese atrial fibrillation patients: a singlecenter experience. PLoS One. 20I5; 10(4):e0I235I6.

19. Kirchhof P, Benussi S, Kotecha D, Ahlsson A, Atar D, Casadei B, et al. 2016 ESC Guidelines for the management of atrial ibrillation developed in collaboration with EACTS. Europace. 2016;18(1I):160978.

20. Pathak RK, Mahajan R, Lau DH, Sanders P. The implications of obesity for cardiac arrhythmia mechanisms and management. Can J Cardiol. 20I5;3I(2):203-I0

21. Thanassoulis G, Massaro JM, O'Donnell CJ, Hoffmann U, Levy D, Ellinor PT, Wang TJ, Schnabel RB, Vasan RS, Fox CS, Benjamin EJ. Pericardial fat is associated with prevalent atrial fibrillation: the Framingham Heart Study. Circ Arrhythm Electrophysiol. 2010;3:345-350.

22. Zheng LH, Wu LM, Yao Y, Chen WS, Bao JR, Huang W, Shi R, Zhang $\mathrm{KJ}$, Zhang S. Impact of body mass index on plasma $\mathrm{N}$-terminal ProBtype natriuretic peptides in Chinese atrial fibrillation patients without heart failure. PLoS One. 2014 ;9(8):el 05249.

23. Yagawa MI, Nagatomo Y, Izumi Y, Mahara K, Tomoike H, Shiraishi Y, Kohno T, Mizuno A, Goda A, Kohsaka S, Yoshikawa T; West Tokyo Heart Failure (WET-HF) Registry Collaborative Group. Effect of Obesity on the Prognostic Impact of Atrial Fibrillation in Heart Failure With Preserved Ejection Fraction. Circ J. 2017. PLoS One. 2014;9(8):el05249.
24. Badheka AO, Rathod A, Kizilbash MA, Garg N, Mohamad T, Afonso L, Jacob S. Influence of obesity on outcomes in atrial fibrillation: yet another obesity paradox. Am J Med 2010, 123: 646-5I

25. Lavie CJ, Pandey A, Lau DH, Alpert MA, Sanders P. Obesity and Atrial Fibrillation Prevalence, Pathogenesis, and Prognosis: Effects of Weight Loss and Exercise. J Am Coll Cardiol. 2017;70(16):2022-35.

26. Lip GY, Heinzel FR, Gaita F, Juanatey JR, Le Heuzey JY, Potpara T, Svendsen JH, Vos MA, Anker SD, Coats AJ, Haverkamp W, Manolis AS, Chung MK, Sanders P, Pieske B, Gorenek B, Lane D, Boriani G, Linde C, Hindricks G, Tsutsui H, Homma S, Brownstein S, Nielsen JC, Lainscak M, Crespo-Leiro M, Piepoli M, Seferovic P, Savelieva I. European Heart Rhythm Association/Heart Failure Association joint consensus document on arrhythmias in heart failure, endorsed by the Heart Rhythm Society and the Asia Pacific Heart Rhythm Society. Europace. 2016;18(I):12-36

27. Sandhu RK, Ezekowitz JA, Hijazi Z, Westerbergh J, Aulin J, Alexander JH, Granger CB, Halvorsen S, Hanna MS, Lopes RD, Siegbahn $A$, Wallentin L. Obesity paradox on outcome in atrial fibrillation maintained even considering the prognostic influence of biomarkers: insights from the ARISTOTLE trial. Open Heart. 2018;5(2):e000908. doi: 10.1136/openhrt-2018-000908

28. Wong CX, Sullivan T, Sun MT, Mahajan R, Pathak RK, Middeldorp M, Twomey D, Ganesan AN, Rangnekar G, Roberts-Thomson KC, Lau $\mathrm{DH}$, Sanders P. Obesity and the Risk of Incident, Post-Operative, and Post-Ablation Atrial Fibrillation: A Meta-Analysis of 626,603 Individuals in 5 I Studies. JACC Clin Electrophysiol. 20 I5; I (3): I39- I 52.

29. Wong CX, Abed HS, Molaee P, Nelson AJ, Brooks AG, Sharma G, Leong DP, Lau DH, Middeldorp ME, Roberts-Thomson KC, Wittert GA, Abhayaratna WP, Worthley SG, Sanders P. Pericardial fat is associated with atrial fibrillation severity and ablation outcome. J Am Coll Cardiol. 201 1;57:1745-1751

30. Podrid PJ, Fogel RI, Fuchs TT. Ventricular arrhythmia in congestive heart failure. Am J Cardiol 1992;69:82G-95G.

31. Zipes DP, Camm AJ, Borggrefe M, Buxton AE, Chaitman B, Fromer $M$, et al. Guidelines for management of patients with ventricular arrhythmias and the prevention of sudden cardiac death. Executive summary. Circulation. 2006; I 14:1088-132.

32. González-Cambeiro MC, Rodríguez-Mañero M, Abellas-Sequeiros A, Moreno-Arribas J, Filgueira-Rama D, González-Juanatey JR. Prognostic Effect of Body Mass Index in Patients With an Implantable Cardioverter-defibrillator for Primary Prevention of Sudden Death. Rev Esp Cardiol (Engl Ed). 2016;69(I0):990-92.

33. Szepietowska BI, McNitt S, Polonsky B, Sherazi S, Biton Y, Kutyifa V, Aktas MK, Moss AJ, Zareba W. Metabolic syndrome is associated with different clinical outcome after cardiac resynchronization therapy in patients with ischemic and non-ischemic cardiomyopathy. Cardiol J. 2016;23(3):344-5I. 